\title{
Issues of social pedagogy in „Studia Pedagogiczne"*
}

A B S T R A C T: For almost seven decades "Studia Pedagogiczne" have accompanied the achievements of Polish pedagogues It is a testimony to their interests, transformations, development; the changes undergone in many spheres by the entire environment. The aim of the text is to look at the issues taken up in the journal in the perspective of time; at the thematic areas taken up by the authors and the participation of social pedagogues in representing their research interests. It is impossible to cover the reflections resulting from several dozen issues on several pages of this text, therefore special attention has been focused on the last area, i.e. the area related to social pedagogues. They, especially the people gathered around the Department of Social Pedagogy of the University of Warsaw, created several independent volumes of the magazine, and Ryszard Wroczyński spent many years building the character of "Studia Pedagogiczne" as a member of the Editorial Team.

KE YW ORDS: "Studia Pedagogiczne", social pedagogy, social pedagoges.

The first issue of the magazine was published in 1954. It was signed by the Polish Academy of Sciences and realized by the Committee on Education Studies. This publication was treated as a success of the pedagogical community, proving their scientific significance.

* Selected text fragments can be found in the text by W. Danilewicz: "Studia Pedagogiczne": its relationship to changing times, "Polish Journal of Educational Studies", 2018, Vol. I (71); https://cotent.sciendo.com/view/journals/poljes/71/1/article-p1.xml. 
The first three volumes constituted a collection of materials from various areas, i.e. mainly pedagogy, psychology, history (especially the history of education). The subsequent volumes addressed issues from the field of pedagogical sub-disciplines or significant areas of interest, such as: social pedagogy; special pedagogy, didactics, history of education, adult education, pre-school and early childhood pedagogy, childcare pedagogy, comparative pedagogy, pedeutology, education management, work pedagogy.

The issues addressed were changing, but also intertwining and repeating. However, they were never the same because of the changeability of political periods and development in different areas of life. Problems of broad significance were noticed and presented, frequently raising issues concerning education, e.g. in volumes: Oświata i pedagogika w Polsce i w świecie. Rok 1969 / Education and pedagogy in Poland and in the world. The year 1969 (Suchodolski 1971, Vol. XXII); Współczesne innowacje $w$ systemie oświaty i wychowania / Modern innovations in the education system (Miller 1976, Vol. XXXVII); Kierowanie oświata i szkoła / Education and school management (Podoski 1980, Vol. XLII) and in the newer publications. These issues were supplemented with content on the role of the school in shaping reality (the existing one and the one that was being pursued), e.g. Z zagadnień organizacji szkolnictwa $w$ Polsce Ludowej / The organization of education in the People's Republic of Poland (Pęcherski 1975, Vol. XXXV) or Szkoła i perspektywy kultury / School and perspectives of culture (Muszyński 1988, Vol. LII); Edukacja szkolna w zmianach? Zmiany $w$ edukacji szkolnej / School education in change? Changes in school education (Dudzikowa, Jaskulska 2011, Vol. LXIV).

Many times attention was paid to the teacher whose profile, development and tasks were changing in interpretations over the years. These issues were discussed in the following volumes: Nauczyciel, tradycje, wspótczesność, przyszłość / The teacher, traditions, presence, future (Wołoszyn, Vol. XXXIX, 1978); Warunki pracy nauczycieli / Working conditions of teachers (Wiloch, 1989, Vol. LIV); Nauczyciel i problemy jego kształcenia $w$ okresie zmiany społecznej 1991-1992 / Teacher and the problems of their education in the period of social change 1991-1992 (Muszyński 1994, Vol. LX).

Slowly, but increasingly, issues have been introduced on the basis of comparative analyses. First within the countries of the Eastern Bloc and, after the opening of the borders, much more widely, e.g. in the volumes: Kwalifikacje $i$ kształcenie kadr pedagogicznych w świecie wspótczesnym / Qualifications and education of teaching staff in the modern world (Wiloch 1991, Vol. LVI).

Another clear area of analysis closely related to education and teacher was related to the didactic aspects of work. And so the 1973 issue was devoted 
to new trends in didactics (1973, Vol. XXV); another one, under the title Nowoczesny podręcznik. Problemy, propozycje, badania / Modern textbook. Problems, propositions, research (Kupisiewicz, Matulka 1976, Vol. XXXVI) covered more detailed issues, especially those focused on didactic literature.

Of course, attention was paid to the student themselves and their development, e.g. in volumes: Rozwijanie aktywności uczniów / Developing student activity (Okoń, 1964, Vol. XI); Poziom umysłowy i zainteresowania młodzieży / Intellectual level and interests of youth (Suchodolski 1965, Vol. XIII), Rozwój i wychowanie dzieci w wieku przedszkolnym / Development and education of children in preschool age (Wilgocka-Okoń 1985, Vol. XLVIII). However, almost until the end of the 20th century, more was written about the student, phases of development, possibilities of support, rather than about the child, childhood (such topics began to be analyzed in the last decade, e.g. in volume XVIII Dzieciństwo i wczesna edukacja. Kontrowersje, problemy, rozwiazania / Childhood and early education. Controversy, problems, solutions (Klus-Stańska, Szyling 2015).

Much space was also devoted to content related to the disabled, although these issues were taken up only after almost twenty years of the magazine's existence, e.g. Współczesne teorie i tendencje wychowania i kształcenia specjalnego / Modern theories and trends in education and special education (Hulek 1979, Vol. XL); Funkcja pedagogiki specjalnej w systemie oświatowo wychowawczym / The function of special education in the education and training system (Hulek 1983, Vol. XLV); Kształcenie i wychowanie dzieci i młodzieży niepetnosprawnej a stużby socjalne - zadania pedagoga / Education and training of children and youth with disabilities and social services - tasks of a pedagogue (Hulek 1992, Vol. LIX).

The value of the magazine from the very beginning of its existence has been the use of works related to psychology, history, philosophy, aesthetics, culture etc. The incorporation of texts by representatives of these disciplines and the use of their achievements by many authors indicates a broad interpretation of pedagogical issues. The texts of prominent representatives of these sciences have been published in many volumes. An example of this can be the excellent editions, e.g. of the volume Problemy wspótczesnego człowieka $w$ filozofi - wartość, wolność, odpowiedzialność / Problems of modern man in philosophy - value, freedom, responsibility (Suchodolski 1971, Vol. XXI). In some volumes, the content strictly reflecting the character and area of interest of a given discipline was discussed, while in others, the texts were of an interdisciplinary nature. 


\section{"Studia Pedagogiczne" in the perspective of changes}

It is not necessary to thoroughly study the content of the texts contained in individual volumes in order to see a clear evolution in several areas, such as political views, scientific thought, theoretical foundations of conducted research, areas of interest, directions of analysis. During the first 30 years of the magazine's existence (in the 50s, 60s, 70s) the political influences were clear; in some volumes in the Editors' Forewords and selected texts there were references to socialist obligations; the narration was also clearly built around them. The intention of founding "Studia Pedagogiczne" according to the first editor of the magazine, Bogdan Suchodolski, was to create "a Marxist pedagogical theory in Poland". (Suchodolski 1954, p. 6). It was also written that "the overthrow of the communist system and the building of the foundations of socialism in our country became the starting point for a profound cultural revolution taking place in these new conditions in the fields of science, art, schooling and education. The changes and achievements of the People's Republic of Poland in the field of organization of schooling and education are particularly significant" (Suchodolski 1954, p. 5). These are words that reflect the political time in the post-war Poland. The time when for almost four decades "Studia" was published under censorship. Censorship, as a part of the socio-political system, reflected its axiology, often forcing the approving expression of "binding attitude towards the existing order". The author of the Introduction to the first volume indicated very clearly the goals of the then-education, i.e. shaping (through education and schooling) the socialist man building the socialist state. In the three-page preamble B. Suchodolski wrote also: "but science can only develop in the atmosphere of creative discussions, which are born out of cognitive passion and a desire to deliberately manage the processes of reality" (Suchodolski 1954, p. 7). The analysis of further pages of the magazine produced over the subsequent decades shows that the quoted "atmosphere of creative discussion" and "cognitive passion" accompanied subsequent editors and authors in a completely different, i.e. open direction.

In the 1970s, a new narrative began to appear in the magazine. For example, in the volume XXI entitled Problemy wspótczesnego człowieka w filozofi - wartość, wolność, odpowiedzialności / Problems of modern man in philosophy - value, freedom, responsibility (Suchodolski 1971), in the Foreword written by Bogdan Suchodolski there are completely different topics than in previous decades. The "problems of modern man" appeared here, 
confronted with values such as freedom and responsibility. It was claimed that "philosophical reflection on the world and man is therefore one of the essential elements of pedagogy and should be practiced in this discipline on an equal footing with its other components" (Suchodolski 1971).

At the same time, in the volume XXX entitled Osobowość w społeczeństwie $i$ kulturze / Personality in society and culture B. Suchodolski confronted traditional pedagogy with new challenges, with "a new dimension of educational processes and educational needs, which is being shaped under the current conditions of existence". It was the first time that the area that Suchodolski described as "the problem of education for existence" appeared (Suchodolski 1974, p. 6). For the first time there also appeared the theme of striving in educational activities to build reflectiveness, "personal culture" and "culture of coexistence" in confrontation with consumer attitudes that "take away the value of human life always when they cross borders". Suchodolski formulated a thesis that modern education, apart from education for professional work and social activity, must strive to teach "a full, happy life". (Suchodolski 1974, p. 6). The title of this issue and the selection of texts resulted, among others, from the publication of the book edited by Edgardo Faure, Learning to be. The world of education today and tomorrow, (Faure 1972). New ideas and educational tendencies slowly began to flow in, especially as the 1970s and 1980s were a time when Poles, to a limited extent, but more often than before, traveled abroad. These contacts resulted in joint scientific undertakings, e.g. in the volume LII entitled Szkoła i perspektywy kultury / School and Cultural Perspectives (Muszyński 1988), which were the result of an international PolishGerman seminar. Such references have been made in subsequent years and decades. Gradually, texts based on the international experience of the authors began to appear. In 1963, in the volume X entitled Srodowisko i wychowanie. Zbiór rozpraw z pedagogiki społecznej / Environment and education. The collection of essays on social pedagogy there are the first references to Western literature, resulting from the participation of the editor of the volume Ryszard Wroczyński - in the Pedagogical Congress in Oslo in 1961. In 1965, in the publication entitled Poziom umystowy i zainteresowania młodzieży / The intellectual level and interests of youth (1965, Vol. XIII) the attention was drawn to the text by Jan Konopnicki entitled International research on the level of knowledge of thirteen-year-old children (the purpose, organization and conduct of research and general analysis of the results), there are numerous references to researchers and their works from outside of the Eastern Bloc (as such were obviously represented). The change of the one-sided narrative resulted from the fact that Polish researchers addressed issues with broad, global references, 
especially after Poland's accession to the European Union (Gajdzica 2017, Vol. LXX).

Let us return to the previous decades. Here, in the 1980s and 1990s, there are further, new issues discussed by the authors, e.g. in volume XLVIII entitled Rozwój i wychowanie dzieci w wieku przedszkolnym / Development and education of children in preschool age (1985, Vol. XLVIII). Such issues had not been addressed before. Noteworthy is the title of the volume XLI Kwalifikacje $i$ kształcenie kadr pedagogicznych $w$ świecie wspótczesnym / Qualifications and education of teaching staff in the modern world (1991, Vol. XLI). There has never been such a broadly formulated, i.e. referring to global phenomena, topic before.

And finally, another change - the most important one, resulting from the change of the political system and opening of the borders of Poland. In the issue no. LX entitled Nauczyciel i problemy jego kształcenia $w$ okresie zmiany spotecznej 1991-1992 / Teacher and the problems of their education in the period of social change 1991-1992 (Muszyński 1994, Vol. LX), the editor Heliodor Muszyński stated that the texts contained therein "cover a wide panorama of issues concentrated around one of the most crucial problems faced by the educational system: the problem of preparing the teaching staff to work in a new school, in new conditions, for the benefit of a new, emerging society". (Muszyński, 1994, Vol. LX, p. 5).

H. Muszyński listed, citing O. Anweiler (1991), "the main directions of changes that must take place in the countries of real socialism if they want to build a fully democratic society". (Muszyński 1994, p. 7). Among them there were points such as: "from a centrally directed society to a decentralized society; [...] from a society based on centralization to one based on participation" and others, equally important (O. Anweiler, 1991). It was agreed that such a level of democracy could not be achieved "without good education [...] and without a »new « teacher" (Muszyński 1994, Vol. LX, p. 8).

The changes taking place in the biography of the magazine are evidenced by other examples, no longer related to the issues discussed. These are, for example, references to literature. In many texts from the initial period of its functioning, only authors from other socialist countries were quoted. It should be clearly recalled here that access to the so-called Western literature was difficult and it was impossible to mention sources not accepted by the authorities. However, in many texts, even at an early stage (although more often in the 1970s and 1980s), the authors managed to avoid such a narrative. Many of them did very well, referring, for example, to the classics of philosophy. Others, in turn, presented the results of their own research analyzing them 
on the basis of the data received. Analyses based on historical facts were also conducted with the use of available sources.

The above mentioned areas of changes are of course of a selective nature. For all the years of its existence it has been a panorama of thoughts and views, but most of all it is a testimony to the development of pedagogy in Poland. The past years have been the time of individual stories of every volume and the collective, overall face of the magazine. The mentioned areas of theory and practices undertaken in the magazine are a modest illustration of the multitude of discussed issues. Their value and the importance of the magazine is undeniable. All the more so because the authors of many texts were outstanding representatives of science, including Władysław Tatarkiewicz, Tadeusz Kotarbiński, Stefan Szuman, Maria Grzegorzewska, Bogdan Nawroczyński, Maria Przetacznikowa, Wincenty Okoń, Jan Konopnicki, Czesław Kupisiewicz, Ignacy Szaniawski, Irena Wojnar, Aleksander Kamiński, Lucjan Turos. It was here that the first texts of excellent social pedagogues, Tadeusz Pilch, Barbara Smolinska-Theiss, Wiesław Theiss, Ewa MarynowiczHetki, Mikołaj Winiarski, Jerzy Nikitorowicz, Krystyna Marzec-Holka and others were published.

\section{Social pedagogues in "Studia Pedagogiczne"}

Social pedagogy has accompanied the seventy-year history of "Studia Pedagogiczne" almost from the beginning of its edition. First of all, for several years Ryszard Wroczyński was a member of the Editorial Committee (or the Editorial Team - the name was changed, note by WD) as the editorin-chief or a member of this body. He was also the author of many texts and a scientific editor of individual volumes, especially those from the series Rozprawy z pedagogiki społecznej / Essays on social pedagogy. They represented mainly the circle of Warsaw social pedagogues, but also many researchers from other centers.

Volume X (1963) begins a thematic cycle devoted to the aforementioned essays on social pedagogy. The scientific editor of the volume entitled Środowisko $i$ wychowanie. Zbiór rozpraw z pedagogiki społecznej / Environment and education. Collection of essays on social pedagogy was Ryszard Wroczyński, who collected essays on the titular "issues of environmental conditions of educational processes”. (Wroczyński, 1963, Vol. X, p. 5). The work consists of an introduction by Ryszard Wroczyński and nine essays based on field research conducted in the years 1957-1961. They concern the following issues: the influence of parents' alcoholism on the school fates of children 
and youth (Majewska), the influence of school failures on the fates of youth (Izdebska), environmental conditions of school failures (Sobkowicz), social functions of a school in a new place of residence, i.e. in a new housing estate (Kukołowiczowa, the original note by WD; TS), the professional fates of young workers (Mazurkiewicz), the fates of graduates of preparatory courses for university studies and its conditions (Frelik) and the issue of free time presented in three texts by the authors (Wujek, Chudzińska, Giereluk). The texts are of a research and analytical nature, reflecting the reality of the time in various areas of life and in various age groups.

The next edition of the magazine in 1964 also represented social pedagogy. In the volume XII titled Problemy opiekuńcze. Zbiór rozpraw z pedagogiki społecznej / Care problems. Collection of essays on social pedagogy, its scientific editor - Ryszard Wroczyński - focused on pedagogy of care. In the text that opens this edition, the editor presents it as a "young branch of pedagogical sciences" (Wroczyński, 1964, Vol. XII, p. 8), discusses the development of this area of social pedagogy, its assumptions and areas of interest.

The whole volume, in turn, reviews selected issues concerning institutions and forms of care and educational activity (Izdebska), development of the idea of children's friends associations (Kuzańska), development of child care in the Soviet Union (Kelm), the need for the development of social and educational counseling facilities (Papuziński), the caring role of schools in rural communities (Wybkowa-Pawłowska).

A new collection of essays on social pedagogy, i.e. volume XV entitled Organizowanie środowiska wychowawczego / Organization of educational environment, is published in 1967, under the scientific supervision of Ryszard Wroczyński and Tadeusz Wujek. This time, the area of interest was education in the environment, and "in particular the deliberate educational activity in the environment" (Wroczyński, 1967, Vol. XV, p. 6). Justifying the choice of issues, the Editor of the volume emphasized that "the Department of Social Pedagogy of the University of Warsaw has been conducting detailed research on the issues of education in the environment and programming of the educational environment for a number of years. Partial results of these works are presented in this volume, which is the result of the collective effort of the team gathered around the Department in regular or occasional cooperation. Most essays are based on empirical research, although some, taking into account a broader source base, analyze given issues theoretically or are the result of studies abroad" (Wroczyński, 1967, Vol. XV, p. 10).

The texts are divided into two parts - the first referring to Polish reality, the second to "selected countries, both our camp and capitalist countries" 
(Wroczyński, 1967, Vol. XV, p. 10). In the first part, the authors of the texts were: Ryszard Wroczyński, Jerzy Wołczyk, Albin Kelm, Helena Izdebska, Józef Marczak, Wojciech Marczyk, again Ryszard Wroczyński together with Kajetan Hądzelek and Tadeusz Pilch, Maria Kuzańska, Mikołaj Winiarski, Elżbieta Breitkopf. In the second one: Albin Kelm, Bohdan Tracewski and Bronisław Rybałko, Krzysztof Przecławski, Tadeusz Wujek.

Another important volume created by the team of social pedagogues was the one from 1970, edited by Ryszard Wroczyński and Tadeusz Pilch, entitled Metodologia środowiskowych badań pedagogicznych. Rozprawy z pedagogiki społecznej / Methodology of environmental pedagogical research. Essays on social pedagogy.

The preface written by Ryszard Wroczyński stressed the need for methodological studies in connection with "the aspiration to intensify empirical research in pedagogy" (Wroczyński, Pilch 1970, p. 5). Wroczyński also notes that "the need for pedagogical research, which is felt quite strongly, does not currently find sufficient support in methodological studies that would facilitate a rational procedure when undertaking and carrying out research". (Wroczyński, Pilch 1970, p. 7). Referring to the achievements of other scientific disciplines, he notes that, although "in recent years, a number of methodological publications have been observed in Polish pedagogical literature" (ibid.), but they are focused on specific areas. R. Wroczyński claims that the methodological achievements in the field of research on educational processes is still quite modest, despite the clear interest of the environment, therefore "the systematic outline of the methodology of environmental pedagogical research, which would more comprehensively and exhaustively present, especially to young researchers and a wide range of pedagoguespractitioners, modern methods and techniques of environmental pedagogical research and assessment of the educational environment, remains an open issue. Such a study would undoubtedly enhance the course of empirical research, contribute to its improvement and directly serve the progress of educational practice (Wroczyński, Pilch 1970, p. 8).

The editors of the volume emphasize the role of social pedagogy in building and perfecting the research technique of pedagogues by writing that "the works were conducted in the Department of Social Pedagogy at the University of Warsaw and in the Department of Social Pedagogy at the University of Łódź. It is no coincidence that the initiative of the collection of methodological essays came from the departments of social pedagogy. They represent a branch of pedagogy which generalizations stemmed from the experience of educational practice and which further progress will be 
determined by the improvement of the research technique. (Wroczyński, Pilch 1970, p. 8).

This volume consists of two parts. The first one contains content concerning "research procedures in the analysis of the educational environment and basic research techniques". (Wroczyński, Pilch 1970, p. 8). The authors of the texts are: Ryszard Wroczyński, Aleksander Kamiński, Tadeusz Pilch, Józef Wojtyniak, Tadeusz Wujek, Iza Muchnicka, Roman Janeczko, Władysław Zaczyński, Władysław Sawicki, Mikołaj Winiarski, Jerzy Wołczyk, Albin Kelm, Edward Mazurkiewicz, Wojciech Marczyk, Zbigniew Kwieciński.

The second part of that year's edition contains reports from research and their authors are: Brygida Butrymowicz, Irena Lepalczyk and Iza Muchnicka, Józef Marczak, Mirosław Nowicki, Edmund Trempała, Wanda Wyrobkowa Pawłowska, Elżbieta Breitkopf.

The preface to subsequent essays on social pedagogy entitled Różnorodność sytuacji wychowawczych / Diversity of educational situations was also written by Ryszard Wroczyński, who together with Elżbieta Breitkoff was a scientific editor of the volume XXXIII, 1975 entitled: Potrzeby wychowawcze - ich zaspokajanie. Rozprawy z pedagogiki społecznej / Educational needs their satisfaction. Essays on social pedagogy (Wroczyński and Breitkoff 1975, Vol. XXXIII). In the texts that comprise this volume, the authors did indeed refer to the various educational situations of the time, which were contained in seven areas:

- Rodzina i wychowanie / Family and education - Zofia Lubowicz, Bożenna Kamińska, Aleksandra Majewska,

- Funkcjonowanie placówek wspomagających rozwój dzieci i młodzieży I Functioning of institutions supporting the development of children and youth - Jadwiga Walczyna, Barbara Passini, Henryk Gąsior,

- Srodowisko a aspiracje życiowe młodzieży wiejskiej / Environment and life aspirations of rural youth - Zofia Kosel, Genowefa Pańtak, Wiesław Theiss,

- Problemy opiekuńcze w zakładach opieki calkowitej / Care problems in long-term care facilities - Albin Kelm, Stanisława Nowaczyk, Maria Kuzańska, Teresa Piotrowska-Opolska,

- Szkoła i wychowanie / School and education - Edmund Trempała, Elżbieta Breitkopf, Barbara Smolińska and Bożena Furmaniak, Krystyna Kowalik,

- Wychowawcza rola zakładu pracy / Educational role of workplace Stanisław Czajka. 
After a rather long break the volume XLVI entitled Pedagogika społeczna - poszukiwania i rozstrzygnięcia / Social Pedagogy - search and conclusions (Pilch and Smolińska-Theiss 1984, Vol. XLVI) was published in 1984. The editors are Tadeusz Pilch and Barbara Smolińska-Theiss, who in their Preface Word referred to the tasks of social pedagogy, claiming that: more pressing needs are now posed to our discipline by the world of human relations and the world of living conditions. It seems that the pathology of human relations is now becoming such a distinctive feature of our times that the search for means to overcome it becomes an urgent need. Living conditions cause an increasingly richer stream of danger, helplessness and loneliness - the main sources of social disorganization - to flow through everyday life (Pilch and Smolińska-Theiss, 1984, Vol. XLVI, p. 5).

This volume is opened by Ryszard Wroczyński with a text entitled Nurt pedagogiki społecznej w polskich koncepcjach wychowawczych / The trend of social pedagogy in Polish educational concepts, where he quotes Helena Radlińska, who "postulated a new Polish pedagogical theory - the theory of broad view of the tasks of education, which she described as social pedagogy" (after: Wroczyński, 1984, p. 8). Further content refers to "the most pertinent and controversial problems of our discipline. It contains many thoughts, especially in the theoretical aspect, which should serve well for decisions and methodological findings. There are also essays which are a new attempt to diagnose selected phenomena and institutions, particularly relevant in our difficult reality. We were not avoiding controversial opinions. If the controversies contribute to the progress in conceptual and methodological decisions, if they influence the efficiency of the technique and the accuracy of the diagnosis - the role of publication will be considered fulfilled", write the editors of the volume - T. Pilch, B. Smolińska-Theiss (1984, Vol. XLVI, p. 6).

These "further contents" are divided into four parts, carefully linked thematically. The first one, titled Z refleksji teoretycznej / From theoretical reflection, the topic of theoretical and methodological foundations of social pedagogy and its background is continued by: Adam O. Uziembło, Stanisław Kawula, Anna Przecławska, Tadeusz Pilch, Ewa Marynowicz-Hetka, Barbara Smolińska-Theiss, Elżbieta Breitkoff, Wiesław Theiss.

Diagnoza środowiska wychowawczego / Diagnosis of the educational environment is the title of the second part, where the topics undertaken demonstrate the recognition of new areas of social life and new directions of their interpretation. The following authors contributed to this publication: Andrzej Olubiński, Zdzisław Błażejewski, Jan Badura, Henryk Gąsior, Jadwiga Izdebska, Jerzy Nikitorowicz, Waltraut Kerber-Ganse and Wolfgang Ronge. 
The third part deals with the educational environment and its organization (and so it is titled). It includes content concerning educational institutions undertaken by: Edmund Trempała, Irena Jundziłł, Alicja Wrzesińska, Krystyna Marzec-Holka, Maria Kuchcińska, Marian Kalinowski, Brygida Butrymowicz, Lesław Pytka.

And last part, entitled Kształcenie wychowawców - pedagogów społecznych I Training of educators - social pedagogues, introducing the reader to subsequent areas of interest of social pedagogy of that time, containing texts by Albin Kelm, Róża Pawłowska, Mieczysław Gałaś.

Volume XLVI is a cross-section of issues taken up by social pedagogues representing many scientific centers.

In 1992, the issue of pedagogy of care was addressed for the second time. The editor of volume LVIII entitled Pedagogika opiekuńcza - podstawy metodologiczne i wybrane kierunki opieki nad dzieckiem / Pedagogy of care methodological basics and selected directions of childcare was Edmund Trempała. This publication recognizes the problems of children raised in dysfunctional families, living in care institutions.

Social pedagogues have been publishing the results of their analyses in subsequent editions of "Studia Pedagogiczne", although in more thematically diverse volumes. It was not until 2016 that Maria Mendel presented the issues of the pedagogy of place resulting from the concept of environmental education of Wiesław Theiss (2001) in the LXIX volume entitled Miasto pedagogiczne / Pedagogical city. The texts contained in the volume, written by authors representing various disciplines, referred to theoretical reflection and research on educational practice, which was defined by the pedagogy of the city. This is an example of the development of areas of interest of social pedagogues and their constant connections with social education.

These connections are a permanent element of the scientific work of Tadeusz Pilch. He was publishing together with Ryszard Wroczyński and Kajetan Hądzelek in 1967 as an assistant in the Department of Social Pedagogy at the University of Warsaw. In 1970 he edited a volume of essays on social pedagogy with Ryszard Wroczyński and in 1984 with Barbara Smolinska-Theiss. His work is commented on by people accompanying him in subsequent stages: "the person of Tadeusz Pilch and his socio-scientific activity is a natural link between the "old masters" of social pedagogy and the "new « social pedagogy that has been developing in our country over the last quarter of a century. The student of Ryszard Wroczyński, one of our pedagogical classics, was a witness of ideological attacks directed against the »bourgeois« social pedagogy by the party praetorians of the communist times. Personal freedom, 
courage and service to the truth, scientific honesty and creativity - these are the values that resisted the opponents and built a strong foundation for the Department of Social Pedagogy at the University of Warsaw. It is a long-lasting human and social capital, thanks to which social pedagogy, fully aware of its identity, did not have to urgently search for new content and shapes after 1980. (Konopczyński et al. 2010, p. 8).

The Professor (because this is how we refer to him in the Białystok environment) continues these values, passing them on in subsequent, insightful articles and appeals. His commitment stimulates the pedagogical community to continuously respond to the needs of others.

\section{References}

Dudzikowa M., Jaskólska S. (ed.)., 2011, “Studia Pedagogiczne”, Vol. LXIV: Edukacja szkolna $w$ zmianach? Zmiany w edukacji szkolnej.

Faure E., 1972, Learning to be. The world of education today and tomorrow, UNESCO.

Hulek A. (ed.), 1979, "Studia Pedagogiczne”, Vol. XL: Wspótczesne teorie i tendencje wychowania i kształcenia specjalnego.

Hulek A. (ed.), 1983, “Studia Pedagogiczne”, Vol. XLV: Funkcja pedagogiki specjalnej w systemie oświatowo-wychowawczym.

Hulek A. (ed.), 1992, "Studia Pedagogiczne", Vol. LIX: Kształcenie $i$ wychowanie dzieci i młodzieży niepetnosprawnej a stużby socjalne - zadania pedagoga.

Klus-Stańska D., Szyling G. (ed.), 2015, “Studia Pedagogiczne”, Vol. XVIII: Dzieciństwo i wczesna edukacja. Kontrowersje, problemy, rozwiązania.

Konopczyński M., Theiss W., Winiarski M., 2010, Pedagogika społeczna. Przestrzenie życia i edukacji, Wydawnictwo Pedagogium, Warszawa.

Kupisiewicz C., Matulka Z. (eds.), 1976, “Studia Pedagogiczne”, Vol. XXXVI: Nowoczesny podręcznik. Problemy, propozycje, badania.

Mendel M., (ed.), 2016, Miasto pedagogiczne, Vol. LXIX, Gdańsk: Wydział Nauk Społecznych UG, Warszawa: Wyższa Szkoła Nauk Społecznych Pedagogium.

Miller R. (ed.), 1976, “Studia Pedagogiczne”, Vol. XXXVII: Współczesne innowacje w systemie oświaty i wychowania.

Muszyński H. (ed.), 1988, “Studia Pedagogiczne”, Vol. LII: Szkoła i perspektywy kultury.

Muszyński H. (ed.), 1994, “Studia Pedagogiczne”, Vol. LX: Nauczyciel i problemy jego kształcenia $w$ okresie zmiany społecznej 1991-1992.

Okoń W. (ed.), 1964, “Studia Pedagogiczne”, Vol. XI: Rozwijanie aktywności uczniów.

Okoń W. (ed.), 1973, “Studia Pedagogiczne”, Vol. XXV: Nowe tendencje w dydaktyce.

Pęcherski M. (ed.), 1975, Studia Pedagogiczne, Vol. XXXV: Z zagadnień organizacji szkolnictwa $w$ Polsce Ludowej.

Pilch T., Smolińska-Theiss B. (ed.), 1984, "Studia Pedagogiczne”, t XLVI: Pedagogika społeczna - poszukiwania i rozstrzygnięcia.

Podoski K. (ed.), 1980, “Studia Pedagogiczne”, Vol. XLII: Kierowanie oświata i szkołą.

Suchodolski B. (ed.), 1954, Wstęp, "Studia Pedagogiczne”, Vol. I.

Suchodolski B. (ed.), 1965, "Studia Pedagogiczne”, Vol. XIII: Poziom umysłowy i zainteresowania młodzieży. 
Suchodolski B. (ed.), 1971, “Studia Pedagogiczne”, Vol. XXI: Problemy współczesnego człowieka w filozofi - wartość, wolność, odpowiedzialność.

Suchodolski B. (ed.), 1971, "Studia Pedagogiczne", Vol. XXII: Oświata i pedagogika w Polsce i w świecie. Rok 1969.

Suchodolski B. (ed.), 1974, “Studia Pedagogiczne”, Vol. XXX, Osobowość w społeczeństwie i kulturze.

Suchodolski B., 1971, Przedmowa, “Studia Pedagogiczne”, Vol. XXI: Problemy współczesnego człowieka w filozofii - wartość, wolność, odpowiedzialność.

Suchodolski B. (ed.), 1971, "Studia Pedagogiczne”, Vol. XXI: Problemy współczesnego człowieka w filozofii - wartość, wolność, odpowiedzialność.

Theiss W., 2001, Mała ojczyzna, Wydawnictwo Akademickie “Żak”, Warszawa.

Trempała E. (ed.), 1992, “Studia Pedagogiczne”, Vol. LVIII: Pedagogika opiekuńcza - podstawy metodologiczne $i$ wybrane kierunki opieki nad dzieckiem.

Wilgocka-Okoń B. (ed.), 1985, "Studia Pedagogiczne”, Vol. XLVIII: Rozwój i wychowanie dzieci $w$ wieku przedszkolnym.

Wiloch T. (ed.), 1989, "Studia Pedagogiczne", Vol. LIV: Warunki pracy nauczycieli.

Wiloch T. (ed.), 1991, "Studia Pedagogiczne”, Vol. LVI: Kwalifikacje i ksztatcenie kadr pedagogicznych $w$ świecie współczesnym.

Wołoszyn S. (ed.), 1978, “Studia Pedagogiczne”, Vol. XXXIX: Nauczyciel, tradycje, wspótczesność, przyszłość.

Wroczyński R., 1984, Nurt pedagogiki społecznej w polskich koncepcjach wychowawczych, "Studia Pedagogiczne", Vol. XLVI: Pedagogika społeczna w polskich koncepcjach wychowawczych.

Wroczyński R. (ed.), 1963, “Studia Pedagogiczne”, Vol. X: Środowisko i wychowanie. Zbiór rozpraw z pedagogiki społecznej.

Wroczyński R. (ed.), 1964, “Studia Pedagogiczne”, Vol. XII: Problemy opiekuńcze. Zbiór rozpraw $z$ pedagogiki społecznej.

Wroczyński R., Breitkoff E. (ed.), 1975, “Studia Pedagogiczne”, Vol. XXXIII: Potrzeby wychowawcze - ich zaspokajanie. Rozprawy z pedagogiki społecznej.

Wroczyński R., Pilch T. (ed.), 1970, "Studia Pedagogiczne”, Vol. XIX: Metodologia środowiskowych badań pedagogicznych. Rozprawy $z$ pedagogiki społecznej.

Wroczyński R., Wujek T. (ed.), 1967, “Studia Pedagogiczne”, Vol. XV: Organizowanie środowiska wychowawczego. 